\title{
Influence of Some Natural Substances for Control the Greater Wax Moth Galleria mellonella l. (Lepidoptera: Pyralidae) Asmaa M. Fawzy ${ }^{1,2}$; S. S. Al-Ahmadi ${ }^{2}$ and Hanan M. Al-Hazmi ${ }^{2}$ ${ }^{1-B e e k e e p i n g ~ R e s e a r c h ~ D e p a r t m e n t, ~ P l a n t ~ P r o t e c t i o n ~ I n s t i t u t e ~(P P R I), ~ A g r i c u l t u r a l ~ R e s e a r c h ~}$ Center,Giza,Egypt. \\ 2-Biology Department, Faculty of science, Taibah Universty _._Kingdom of Saudi Arabia (KSA)

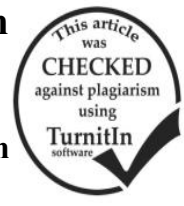

ABSTRACT

The present work studied the effect of some natural substances (Egyptian and Chinese propolis ethanolic extractcinnamon- clove- peppermint ethanolic extract) against the $4^{\text {th }}$ larval instar of G. mellonella. The experiments in this study were conducted in the experimental laboratory of Biology Department, Faculty of Science, Taibah University. Potential activities of active materials on mortality percent and duration of greater wax moth at four concentrations $(0.5,1.0,2.0$ and $4.0 \% \mathrm{w} / \mathrm{w}) \mathrm{were}$ studied, and it is obvious that the mortality effect depend on the kind of materials and concentration. Peppermint ethanolic extract recorded (53.33 $\pm 1.86 \%)$ larvae mortality compare to other materials and control, on other hand the Egyptian propolis ethanolic extract and clove had no effect on great wax moth at $0.5 \%$. the pupa mortality increased in concentration $4 \%$ in Egyptian and Chinese propolis ethanolic extract, cinnamon, clove and peppermint ethanolic extract $(26.66 \pm 0.00,23.33 \pm 1.00,43.33 \pm 4.00$, $33.33 \pm 2.00$ and $8.33 \pm 10.01 \%$, respectively). The adult stage was the more resistance stage. In the larval duration, the highest effect were recorded in peppermint ethanolic extract which recorded $26.67 \pm 3.48$ at $4 \%$ concentration with $31.62 \%$ reduction of normal (control) duration and followed by Chinas propolis and cinnamon ( $30.33 \pm 1.33$ and $30.08 \pm 0.08$ day, respectively) with 22.23 and $22.87 \%$ reduction respectively at $4 \%$ concentration.

Keywords: Control, Galleria mellonella L., Larvae, Propolis, Cinnamon, Clove, Peppermint

\section{INTRODUCTION}

Wax moths are serious pests of bees wax worldwide. The greater wax moth (GWM), $G$. mellonella (Lepidoptera: Pyralidae) is recognized to be harmful to deposited and stored bees wax. G. mellonella the most harmful for apiaries that cause great losses every year, wax combs damage by larval feeding and old frames in the hive. Adult and larvae of wax moths can also transport serious diseases pathogens, e.g. foulbrood. Infested Colonies showed large amounts of causative bacteria spores, Paenibacillus larvaein in wax moth feces (Charriere and Imdorf, 1999).

Possibilities for dominant wax moth including some manipulations in hive and other stored combs treatments i.e. physical,technical, chemical and biological methods e.g. acetic acid ,formic acid and para-dichlorobenzene (Owayss and Abd-Elgayed, 2007). However, these chemicals employ is relatively effective and easy some precautions of bee products safety and contamination were considered. Some of these chemicals showed no effect against wax moth eggs (Fraser, 1997).

In recent years, environmental problems caused by pesticides overuse became scientists and public matter of concern. Synthetic insecticides extensive employ led to beneficial species destruction such as predators and parasites of the pests beside the destruction of $\mathrm{s}$ honey bees as a pollinator's that caused biological imbalance. Natural products are an excellent alternative to synthetic pesticides as a means to decrease negative impacts to human health and the environment (Kwon et al., 1996 and Koul et al., 2008).

Propolis or bee glue is a dark sticky resinous substance gathering by bees from plant sources (Sorkun et al., 2001). The main chemical constituents of propolis are polyphenols (flavonoid aglycones, phenolic acids, and their esters, phenolic aldehydes, alcohols, and ketones), terpenoids, steroids, amino acids, and inorganic molecules (Kartal et al., 2003).
One alternative to synthetic insecticides is the botanical pesticides i.e. insecticidal plants or plant compound and the utilize of natural compounds, such as essential oils. Essential oil and their constituents display to be a potent source of botanical pesticide. The toxicity of a large number of essential oils and their constituents has been estimate against a number of bruchid pests (Keita et al., 2000, 2001 and Tripathi et al., 2002).

In recent years, several essential plant oils had been lead to have repellent properties. Such plants included citronella, cedar, verbena, pennyroyal, geranium, lavender, pine, cinnamon, rosemary, basil, thyme, allspice, garlic and peppermint (Mohinder, 2001 and Rim and Jee, 2006).

Senanayake et al., (1978) reported that the major componants of Cinnamomum zeylanicum of sitting in stem-bark oil and root bark oil are cinnamaldehyde $(75 \%)$ and camphor (56\%) respectively, both were used to control mosquito (Cheng et al., 2004).

Peppermints are the richest source of natural menthol (Sharma and Tyagi, 1991 and Shasany et al., 2000). Peppermint leaves contain about $0.5-4 \%$ volatile oil that is contain of $50-78 \%$ free menthol, menthofurane, monoterpene and traces of jasmine $(0.15 \%)$ to get remarkable oils quality (Dew and Evans, 1984). Peppermint was tested for toxicity and repellency against G. mellonella. (Owayss and Abd-Elgayed, 2007), and Callosobruchus maculates (Aly and Sahar, 2010).

The essential oil of clove oil own a number of bioactive compounds. The chemical constituents of the clove oil had analyzed, and 9 of 18 compounds had distinguish. The main compound (83\%) was Eugenol, the second most common compound (12\%) was transcaryophyllene. These two pure compounds and clove oil were examed for toxicity and repellency against Rhyzopertha dominica, Sitophilus oryzae and Tribolium castaneum. The pure compounds were examed at the dosages found in clove oil (Zeng et al., 2010). Owayss and Abd- Elgayed (2007) also, used clove control against $G$. mellonella. 


\section{MATERIALS AND METHODS}

The experiments were proceed in the experiment laboratory of Biology Department, Faculty of Science, Taibah University located at Al-Madinah AlMunawarah, Kingdom of Saudi Arabia.

\section{1-Rearing of the greater wax moth}

The artificial diet used for rearing the larvae was that described by (PDBC, 2007) mixing the whole wheat bran (100 g), Maize flour $(100 \mathrm{ml})$, Skimmed powdered milk (100g), Dried yeast grains (100g), Honey $(175 \mathrm{ml})$ and Glycerin $(175 \mathrm{ml})$.

Samples of wax combs infested with the greater wax moth were collected from various apiaries in AlMadinah Al-Munawarah. The samples were confined in glass jars, which were tightly locked with plastic cover set up with wire screens to cancel escaping of the insect larvae and were transferred to the insectary and then identified. Rearing larvae were kept under certain laboratory conditions of $30 \pm 2{ }^{\circ} \mathrm{C}$ and $65 \pm 5 \%$ R.H. in dark (Controlled by incubator). The emerged moths of G. mellonella were collected daily and kept in separated glass jars. Jars used for adult mating were provided with soft tissue and piece of cotton moistened with honey bee and small pieces of artificial diet for larvae, all were closed with plastic covers provided with wire screens. The newly hatched larvae burrow tunnels and feed immediately on the artificial diet until they pupate outside and inside the tunnels. Soon after emergence, moths were collected again and provided with fresh artificial diet for larvae.

2- Collection and preparation of the tested materials. Cinnamon (Cinnamomum zeylanicum L.) Inner bark of trees, Clove Syzygium aromaticum L. Flowers buds, Peppermint (Mentha apiperita L) Leaves were obtained from a commercial market as 1/4 kilogram of each and thoroughly cleaned with distilled water to remove debris and later shade dried at room temperature (Mulungu et al., 2007) after drying they were then separately pounded into powder using a pestle and mortar and sieved to obtain the fine powder particles (Mukhtar and Tukur, 2000). saved in the refrigerator until using.

Peppermint leave extract, extraction procedures put up with a previous report of $\mathrm{Yi}$ and Wetzstein (2010). 10g powdered dried leaves, were homogenized and extracted at room temperature under darkness in $100 \mathrm{~mL}$ of $80 \%$ ethanol with agitation on an orbital shaker at $200 \mathrm{rpm}$. The crude extract solutions were filtered and supernatants were collected. The extract obtained by ethanolic solution was incubated at room temperature until ethanol evaporated.

Ethanolic Chinese and Egyptian bee propolis. Chinese and Egyptian propolis was obtained from commercial bee products markets and stored in the refrigerator until using Propolis ethanolic extract was prepared according to (Ildeniz et al., 2004) as follows: Propolis was extracted by maceration at room temperature, with occasional shaking in the proportion of $10 \mathrm{gm}$. of (Chinese and Egyptian) propolis to $100 \mathrm{ml}$ of solvent (ethanol $80 \% \mathrm{v} / \mathrm{v}$ ). Extracts were obtained after 7 days of maceration and filtered. The extracts obtained by ethanolic solution were set at room temperature until ethanol evaporated and the product obtained a honey-like consistence's are named as propolis ethanolic extract.

Four serial concentrations of each materials and ethanolic extract were prepared as followed 0.5, 1.0, 2.0 and $4.0 \mathrm{~g} / 100 \mathrm{~g}$ artificial diet.

3- Effect of tested materials on mortality percentage and duration of different life stages of $G$. mellonella .

The purpose of this experiment was to study the effect of the tested materials against different stages of wax moth (larvae, pupae, adults).Four concentrations of each extract were prepared $0.5 \%, 1.0 \% 2.0 \%$ and 4.0 $\%$.

Prepare 6 groups (control- Egyptian propolis ethanolic extract- Chinese propolis ethanolic extractpeppermint ethanolic extract - cinnamon- clove) each group was treated with the 4 concentrations $(0.5 \%$, $1.0 \%, 2.0 \%$ and $4.0 \%$ ) except control in three replicates. Each replicate contain 10 individuals of $4^{\text {th }}$ larval instar of greater wax moth. They put in glass jars which contain artificial diet. Daily observations for all groups to record the subsequent biological aspects, e.g. mortalities of larvae, pupae and adults. Also, larval duration and pupal duration were recorded.

4. Statistical analysis.

The obtained data was statistically analyzed using analysis of variance (ANOVE) at $0.05 \%$ probability also correlation coefficients were calculated according to the methods given by Snedecor and Cochran (1967).

\section{RESULTS AND DISCUSSION}

\section{1-Effect of tested materials on larval, pupal and} adult wax worm mortality percentage $\%$.

The greater wax moth, Galleria mellonella, is a major pest of beekeeping industry The present study was conducted to explore the effects of five natural materials on the developmental biology and mortality of the life stages of the greater wax moth Galleria mellonella in the laboratory trial.

The potential activities of active materials on mortality percent of the mortality percent of larvae of greater wax moth at four concentration were reported in (Table 1), and it is obvious that the mortality effect depend on the kind of materials and concentration ,the Chinese propolis ethanolic extract (3and 4\%) , cinnamon, clove and peppermint ethanolic extract at concentration $4 \%$ were the highest effective materials on the larval mortality $\%$, The peppermint ethanolic extract was $(53.33 \pm 1.86 \%)$ mortality compare to other materials and control, on other hand the Egyptian propolis ethanolic extract and clove had no effect on great wax moth at $0.5 \%$.

In addition, in pupa stage the concentration $0.5 \%$ in propolis ethanolic extract, cinnamon and peppermint ethanolic extract had no effect on the pupa stage of great wax moth $(0.00 \pm 0.00)$, but the mortality increased in concentration 4\% in Egyptian and Chinese propolis ethanolic extract, cinnamon, clove and peppermint ethanolic extract $(26.66 \pm 0.00,23.33 \pm 1.00,43.33 \pm 4.00$, $33.33 \pm 2.00$ and $8.33 \pm 10.01$, respectively). 
Table 1. Effect of tested materials on larval, pupal and adult wax worm mortality percentage $\%$.

\begin{tabular}{|c|c|c|c|c|c|c|c|c|}
\hline \multirow{3}{*}{$\begin{array}{l}\text { Concentration } \\
\%(w / w)\end{array}$} & \multirow{3}{*}{ control } & \multicolumn{4}{|c|}{ larval stage } & \multirow{3}{*}{ Clove } & \multirow{3}{*}{$\mathbf{F}$} & \multirow[b]{3}{*}{$\mathbf{L S D}_{0.05}$} \\
\hline & & \multirow{2}{*}{\multicolumn{2}{|c|}{$\begin{array}{l}\text { Ethanolic ex } \\
\text { Propolis }\end{array}$}} & \multirow[b]{2}{*}{ Peppermint } & \multirow[b]{2}{*}{ Cinnamon } & & & \\
\hline & & & & & & & & \\
\hline$\overline{0.5}$ & & $0.00 \pm 0.00^{\mathrm{Cc}}$ & $13.33 \pm 1.16^{\mathrm{Ac}}$ & $13.00 \pm 9.01^{\mathrm{Ad}}$ & $7.00 \pm 9.01^{\mathrm{Bd}}$ & $0.00 \pm 0.00^{\mathrm{Cd}}$ & 216.88 & 1.40 \\
\hline 1.0 & 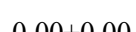 & $6.66 \pm 9.01 \mathrm{~Eb}$ & $33.33 \pm 2.00^{\mathrm{Ab}}$ & $20.00 \pm 0.00^{\mathrm{Cc}}$ & $26.66 \pm 4.00^{\mathrm{Bc}}$ & $13.33 \pm 3.00^{\mathrm{Dc}}$ & 333.36 & 1.81 \\
\hline 2.0 & $0.00 \pm 0.00$ & $13.33 \pm 3.00^{\mathrm{Da}}$ & $40.00 \pm 3.47 \mathrm{Aa}$ & $33.00 \pm 0.00^{\mathrm{Bb}}$ & $33.00 \pm 2.00^{\mathrm{Bb}}$ & $20.00 \pm 0.00^{\mathrm{Cb}}$ & 354.83 & 1.82 \\
\hline 4.0 & & $13.33 \pm 9.01 \mathrm{Da}$ & $40.00 \pm 3.47 \mathrm{Ba}$ & $53.33 \pm 1.86^{\text {Аа }}$ & $40.00 \pm 0.00^{\mathrm{Ba}}$ & $33.33 \pm 2.00 \mathrm{Ca}$ & 640.04 & 1.81 \\
\hline $\mathrm{F}$ & & 137.57 & 475.30 & 942.17 & 942.17 & 770.25 & & \\
\hline $\mathrm{LSD}_{0.05}$ & & 1.63 & 1.88 & 1.89 & 1.89 & 1.63 & & \\
\hline & & & Pup & stage & & & & \\
\hline$\overline{0.5}$ & & $0.00 \pm 0.00^{\mathrm{Bd}}$ & $0.00 \pm 0.00^{\mathrm{Bc}}$ & $0.00 \pm 0.00^{\mathrm{Bb}}$ & $0.00 \pm 0.00^{\mathrm{Bd}}$ & $6.66 \pm 9.01^{\mathrm{Ad}}$ & 133.66 & 0.81 \\
\hline 1.0 & & $6.66 \pm 9.01 \mathrm{Bc}$ & $0.00 \pm 0.00^{\mathrm{Cc}}$ & $0.00 \pm 0.00 \mathrm{Cb}$ & $7.00 \pm 9.01 \mathrm{Bc}$ & $17.00 \pm 3.00 \mathrm{Ac}$ & 242.93 & 1.40 \\
\hline 2.0 & $0.00 \pm 0.00$ & $13.33 \pm 3.00^{\mathrm{Cb}}$ & $11.11 \pm 11.76^{\mathrm{Db}}$ & $0.00 \pm 0.00^{\mathrm{Eb}}$ & $16.66 \pm 3.00^{\mathrm{Bb}}$ & $20.00 \pm 0.00^{\mathrm{Ab}}$ & 217.69 & 1.62 \\
\hline 4.0 & & $26.66 \pm 0.00^{\mathrm{Ca}}$ & $23.33 \pm 1.00^{\mathrm{Da}}$ & $8.33 \pm 10.01^{\mathrm{Ea}}$ & $43.33 \pm 4.00 \mathrm{Aa}$ & $33.33 \pm 2.00^{\mathrm{Ba}}$ & 501.66 & 1.81 \\
\hline $\mathrm{F}$ & & 518.32 & 742.38 & 208.16 & 208.16 & 362.37 & & \\
\hline $\mathrm{LSD}_{0.05}$ & & 1.63 & 1.33 & 0.94 & 0.94 & 1.88 & & \\
\hline & & & Adul & stage & & & & \\
\hline$\overline{0.5}$ & & $0.00 \pm 0.00^{\mathrm{Aa}}$ & $0.00 \pm 0.00^{\mathrm{Aa}}$ & $0.00 \pm 0.00^{\mathrm{Ab}}$ & $0.00 \pm 0.00^{\mathrm{Ab}}$ & $0.00 \pm 0.00^{\mathrm{Ab}}$ & 1.0 & 0.04 \\
\hline 1.0 & & $0.00 \pm 0.00^{\mathrm{Aa}}$ & $0.00 \pm 0.00^{\mathrm{Aa}}$ & $0.00 \pm 0.00^{\mathrm{Ab}}$ & $0.00 \pm 0.00^{\mathrm{Ab}}$ & $0.00 \pm 0.00^{\mathrm{Ab}}$ & 1.0 & 0.05 \\
\hline 2.0 & $0.00 \pm 0.00$ & $0.00 \pm 0.00$ Aa & $0.00 \pm 0.00^{\mathrm{Aa}}$ & $0.00 \pm 0.00^{\mathrm{Ab}}$ & $0.00 \pm 0.00^{\mathrm{Ab}}$ & $0.00 \pm 0.00^{\mathrm{Ab}}$ & 1.0 & 0.04 \\
\hline 4.0 & & $0.00 \pm 0.00^{\mathrm{Ca}}$ & $0.00 \pm 0.00 \mathrm{Ca}$ & $8.33 \pm 1.67 \mathrm{Ba}$ & $41.16 \pm 5.01 \mathrm{Aa}$ & $8.33 \pm 1.67 \mathrm{Ba}$ & 1455.3 & 1.40 \\
\hline $\mathrm{F}$ & & 1.0 & 1.0 & 208.16 & 5082.4 & 208.16 & & \\
\hline $\mathrm{LSD}_{0.05}$ & & 0.05 & 0.05 & 0.94 & 0.94 & 0.64 & & \\
\hline
\end{tabular}

Means followed by the same letter in each column are not significantly different at ( $p>0.05)$

The adult stage was the more resistance stage to all materials under studied and at all concentration accept cinnamon, clove , peppermint ethanolic extract at $4 \%$ recorded $(41.16 \pm 5.01,8.33 \pm 1.67$ and $8.33 \pm 1.67$, respectively)

As shown in the same table, there are a significant differences among all mean values of tested materials on mortality percent of larval, pupal and adult of greater wax moth at four concentration and The percentage observed mortality mortality were significantly increase by increasing the materials under study concentrations

\section{2- Effect of tested materials on larval and pupal} duration /day.

Table (2) reported the effect of tested materials under investigation on the duration of larval and pupa stage of great wax moth. In the larval stage the highest effect were recorded in peppermint treatment which recorded $26.67 \pm 3.48$ at $4 \%$ concentration with $31.62 \%$ reduction of normal ( control) duration and followed by Chinese propolis and cinnamon $(30.33 \pm 1.33$ and $30.08 \pm 0.08$ day, respectively) with 22.23 and $22.87 \%$ reduction respectively at $4 \%$ concentration. On the other hand the Egyptian propolis and clove treatment had no effect on larval duration at $0.5 \%$ concentration. In addition, in pupa stage the Egyptian propolis at $0.5 \%$, Chinese propolis at $0.5,1.0 \%$, cinnamon at $0.5 \%$ and peppermint at $0.5,1.0,2.0 \%$ had no effect on the pupa duration of great wax moth, but the more effectible were cinnamon and clove treatment $(8.35 \pm 1.45$ and $9.33 \pm 0.67$, respectively, at $4 \%$ concentration with 56.05 and 50.89 reduction $\%$. The clove activity showed high significant differences among all concentration from $0.5 \%$ to $4.0 \%$ concentrations. The statistical analysis showed asignificant differences among all mean values of tested materials on pupal duration/day of $G$. mellonella.

Our natural materials provided effective control to wax moths pest, this may be due to the phytochemical composition of secondary metabolite diversity in the samples under investigation, it can inhaled, ingested or skin absorbed by insects. And The fumigant toxicity repellency and toxicity at higher concentration accelerated larva and/or pupa development stage/stages. The abnormally higher rate of development may lead to malformed and immature individuals.

In recent years, searching for environmentally safe methods to control insect pests has been carried out using plant derivatives with significant insecticidal effects, which have been considered as new source of pesticides with negligible side effects on the environment (Balandrin et al., 1985). Several wild plant extracts or isolated active compounds have been shown to act as potent acute or chronic insecticides (Emara et al., 2002; Tripathy and Singh, 2005 and Moawad and Ebadah 2007). Antifeedant, (Salem et al., 2003; Shishir et al., 2004 and Erturk, 2006) and insect growth regulators (Abou El-Ghar et al., 1996) against a variety of insect species. The use of gamma radiation and plant extract are the most promising new approaches for controlling this insect. The combined effects of gamma irradiation and bioinsecticides on Lepidopterous insects have been studied by several authors (Sallam et al., 1991; Mohamed, 2004; Mohamed et al., 2004; El-Shall and Mohamed, 2005 and Mohamed, 2013). Plants may provide potential alternatives to currently used insectcontrol agents because plants constitutions were considered as rich source of bioactive chemicals (Wink, 1993). Additionally, plant-derived materials are found to be highly effective against insecticide resistant insect pests (Kwon et al., 1996), so that many investigators initiated a large screening efforts poisonous effects to use them as insecticides(El-Shazly and Hussien, 2004; Prowse et al., 2006; Malarvannan and Subashini, 2007 and Khalaf et al., 2009).

In recent years, searching for environmentally safe methods to control insect pests has been carried out using plant derivatives with significant insecticidal effects, which have been considered as new source of pesticides with negligible side effects on the environment (Balandrin et al., 1985). 
Table 2. Effect of tested materials on larval and pupal duration /day.

\begin{tabular}{|c|c|c|c|c|c|c|c|c|c|c|c|c|}
\hline & & & & & lar & val stage & & & & & & \\
\hline & & & & Ethanolic ext & tract & & & & & & & \\
\hline & & & Propol & lis bees & & & & cinnamor & & clove & & \\
\hline Concentration & Control & Egyptian & & Chinese & & peppermi & & & & & $\mathbf{F}$ & $\mathbf{L S D}_{0.05}$ \\
\hline & & Duration & $\begin{array}{c}\% \\
\text { red } \\
\end{array}$ & Duration & $\begin{array}{c}\% \\
\text { red } \\
\end{array}$ & Duration & $\begin{array}{c}\% \\
\text { red }\end{array}$ & Duration & $\begin{array}{c}\% \\
\text { red }\end{array}$ & Duration & $\begin{array}{c}\% \\
\text { red }\end{array}$ & \\
\hline 0.5 & & $39.00 \pm 2.3^{\mathrm{Aa}}$ & 0.00 & $36.67 \pm 0.67^{\mathrm{Ba}}$ & 5.97 & $35.75 \pm 2.41^{\mathrm{Ba}}$ & 8.33 & $35.80 \pm 1.47^{\mathrm{Ba}}$ & 8.21 & $39.00 \pm 0.67^{\mathrm{Aa}}$ & 0.008 .11 & 1.81 \\
\hline 1.0 & $300 \Omega$ & $36.00 \pm 1.00^{\mathrm{Ab}}$ & 7.69 & $35.33 \pm 0.33^{\mathrm{Aa}}$ & 9.41 & $33.08 \pm 1.47^{\mathrm{Bb}}$ & 15.18 & $34.75 \pm 0.63$ & 10.20 & $36.13 \pm 0.13$ & 12.493 .58 & 1.82 \\
\hline 2.0 & & $33.67 \pm 0.88^{\mathrm{ABc}}$ & 13.67 & $33.67 \pm 0.88^{\mathrm{ABa}}$ & a 13.67 & $32.67 \pm 0.33^{\mathrm{Bb}}$ & 16.23 & $35.33 \pm 0.48^{\mathrm{Aa}}$ & 9.41 & $34.08 \pm 0.31 \mathrm{ABa}$ & a 12.622 .77 & 1.81 \\
\hline 4.0 & & $33.67 \pm 0.33^{\mathrm{Ac}}$ & 13.67 & $30.33 \pm 1.33^{\mathrm{Ba}}$ & 22.23 & $26.67 \pm 3.48^{\mathrm{Cc}}$ & $=31.62$ & $30.08 \pm 0.08^{\mathrm{Ba}}$ & 22.87 & $33.73 \pm 0.22$ & 13.5132 .86 & 1.82 \\
\hline $\mathrm{F}$ & & 20.27 & & 22.79 & & 44.07 & & 72.75 & & 17.54 & & \\
\hline $\mathrm{LSD}_{0.05}$ & & 1.917 & & 1.87 & & 1.88 & & 1.88 & & 1.88 & & \\
\hline & & & & & $\mathrm{Pu}$ & pa stage & & & & & & \\
\hline 0.5 & & $19.00 \pm 0.00^{\mathrm{Aa}}$ & 0.00 & $19.00 \pm 0.88^{\mathrm{Aa}}$ & 0.00 & $19.00 \pm 1.86^{\mathrm{Aa}}$ & 0.00 & $19.00 \pm 2.33^{\mathrm{Aa}}$ & 0.00 & $13.00 \pm 0.58^{\mathrm{Ba}}$ & 31.5821 .60 & $0 \quad 1.819$ \\
\hline 1.0 & & $14.33 \pm 0.88^{\mathrm{Bb}}$ & 24.58 & $19.00 \pm 0.67^{\mathrm{Aa}}$ & 0.00 & $19.00 \pm 2.08^{\mathrm{Aa}}$ & 0.00 & $14.67 \pm 0.88^{\mathrm{Bb}}$ & 24.58 & $10.33 \pm 1.33^{\mathrm{Cbc}}$ & 45.6339 .96 & $\begin{array}{ll}6 & 1.82\end{array}$ \\
\hline 2.0 & $19.00 \pm 1.16$ & $11.33 \pm 0.88^{\mathrm{Bc}}$ & 40.37 & $11.00 \pm 0.58^{\mathrm{Bb}}$ & 42.11 & $19.00 \pm 0.58$ & 0.00 & $10.67 \pm 0.67^{\mathrm{Bc}}$ & 43.84 & $10.75 \pm 1.28^{\mathrm{Bb}}$ & 43.4242 .12 & 1.82 \\
\hline 4.0 & & $10.33 \pm 0.38^{\mathrm{Bc}}$ & 45.63 & $10.00 \pm 0.58^{\mathrm{BCb}}$ & b 47.37 & $13.00 \pm 0.58^{\mathrm{Ab}}$ & 31.58 & $8.35 \pm 1.45^{\mathrm{Cd}}$ & 56.05 & $9.33 \pm 0.67^{\mathrm{BCc}}$ & 50.8912 .18 & $8 \quad 1.81$ \\
\hline $\mathrm{F}$ & & 45.45 & & 97.00 & & 54.00 & & 131.44 & & 14.42 & & \\
\hline$\underline{\mathrm{LSD}_{0.05}}$ & & 1.88 & & 1.63 & & 1.33 & & 1.33 & & 1.33 & & \\
\hline
\end{tabular}

Aly and Sahar (2011) proved that the peppermint oil and powder are promising as alternatives to chemical control used against Sitophilus oryzae in wheat grains. Also, these peppermint products submit a solution of resistance development by insect due to the presence of a lot of bioactive components rather than the single insecticide. Swamy et al. (2006) observed that, the highest reduction in larval population was observed in pongamia oil $(56.42 \%)$ followed by neem oil $(62.57 \%)$ and mahua oil $(63.09 \%)$. The lowest larval mortality of G. mellonella was obtained with pongamia seed kernel extract which recorded $(9.28 \%)$ and neem seed kernel extract that recorded (11.78\%).

Similar results were obtained in a study by Abdelrahman et al. (2012) whose proved that, peppermint and ginger were the most toxic oils against middle and late larval instars of Galleria mellonella than lemon and camphor.

The present findings agree with Abdelrahman et al. (2012) they demonstrated that peppermint and ginger were the most toxic oils against pupal stage of $G$. mellonella than lemon, camphor. Assegid et al. (2004) found that $2 \%$ and $4 \%$ propolis recorded $40 \%$ and $100 \%$ abortion of pupal metamorphosis and then died. Peppermint were supposed to make good companion plants, repelling pest insects and attracting beneficial ones. Peppermint are susceptible to whitefly and aphids (Ortiz, 1992). Abdelsalam (2009) stated that higher reduction percentages of $G$. mellonella fecundity (90\%) were obtained when treated with the higher doses of either peppermint or lemon oil. Mortality of $100 \%$ were maintained using any tested doses of lemon oil or the higher doses of peppermint oil. Only peppermint and lemon oils caused significant decrease of emerged adults when used at the higher doses.

The discovery of natural materials in propolis, which has no side effects, but in the fact this substances interfere with the biological processes of insects as development, moulting, reproduction and hibernation, and its role is currently only breach of physiological and biochemical processes in insect (Browers, 1984 and Klocvke et al., 1986).

Propolis extract dissolved in 55\% ethanol at higher concentrations caused significantly higher mortality to wax moth larvae than the lower concentrations and untreated controls $24 \mathrm{hrs}$ after treatment the larvacidal action of propolis increases with the concentrations. However, the larvae of wax moth responded similarly to all concentrations $48 \mathrm{hrs}$ but significantly more larvae up to $90 \%$ were killed in propolis treated than the controls. On the other hand, adult emergence was observed in treatments of higher concentrations. This may suggest propolis extract at higher concentration accelerated larva and/or pupa development stage/stages. from different concentration of propolis, 8 and $10 \% \mathrm{w} / \mathrm{v}$ were the most toxic causing $90 \%$ and $80 \%$ mortality. These results indicate higher concentrations were more toxic Zewdu and Gemechis (2016). Assegid et al. (2004) investigated that the treatment of the late $7^{\text {th }}$ stage with non-lethal doses of propolis shortened the duration of pupal metamorphosis significantly. Chandel et al. (2003) demonstrated that the duration of the pupal stage was 19.4 days in active generations and 147.9 days in overwintering generation of G. mellonella.. Pastagia and Patel(2007) stated that pupal stage lasts for 12 to 19 days.. Propolis accelerates the development of the larval/pupal stage of Galleria mellonella. The unusually higher rate of metamorphosis may lead to malformed and immature individuals (Assegid et al., 2004).

The sixth and seventh larval instars were reported to be more sensitive to treatments with propolis concentrations of $10 \%$ propolis that was resulted in $100 \%$ mortality of seventh larval instars. The abnormally higher rate of development may lead to malformed and immature individual's .On the other hand, earlier adult emergence was observed in treatments of higher concentrations. This may suggest propolis extract at higher concentration accelerated larva and/or pupa development stage/stages. The abnormally higher rate of development may lead to malformed and immature individuals (Garedew et al.,2004).

In general, the use of propolis as an insecticide may help us to minimize the problem environmental pollutions as result of synthetic insecticide applications. It also helps to reduce the constantly increasing problem of insecticide resistance development. Since propolis is 
a complex natural product, having different components with various modes of action is unlikely or very slow (Imdorf et al., 1999).

Hany (2013) stated that the essential oils of Camphor, Castor, Cinnamon, Clove and mustard with $1 \%$ concentration repelled the adult Callosobruchus maculates except the castor oil. Non-significant repellent effect was found in $0.01 \%$ concentration in all tested essential oils.As a result of the presence of the essential oil of clove the nerve cord protein was significantly affected as a result of the binding of $3 \mathrm{H}$ octopamine with it. Accordingly, the lack of octopamine receptors in vertebrates likely accounts for the specific mammalian selectivity of essential oils as insecticides (i.e. they are toxic to insects but not to mammals) and thus the octopaminergic system of insects represents a biorational target for insect pest control (Enan et al. 1998). Clove bud oil has biological activities, such as antibacterial, antifungal, insecticidal and antioxidant properties, and are used traditionally as flavoring agent and antimicrobial material in food (Lee and Shibamoto, 2001; Huang et al., 2002 and Velluti et al.,2003).

Extract of leaves of Ocimum viride gave the most effective in $T$. castaneum control and $S$. oryzae, then that of $C$. odorata. On the other hand strong repellent activity gave by $O$. viride with less than $25 \%$ survival reduction at $0.1 \mathrm{mg} \mathrm{ml}-1$. (Owusu, 2000).

The essential oils toxic effect, commonly, essential oils can be ingested, inhaled or absorbed by insects. Their fumigant toxicity control 27 oils, the volatile monoterpenes, has been described (Netzurubanza, 1991; Regnault-Roger et al., 1993 and Regnault-Roger and Hamraoui, 1995). Some essential oils components contain repellent and larvicidal action: $O$. basilicum exerted a larvicidal activity evaluated at EC50 was 81 ppm (Chokechaijaroenporn et al., 1994).

The plants produced secondary metabolites have great activities that affect cellular, tissue and organismal level of insects. In general, they disturb physiological and cellular processes responsible for homeostasis maintenance, and provoke sublethal changes within various tissues and organs, that lead to death. However, secondary metabolites also have sublethal implications, such as reduced fecundity, reduced viability or deformities in parental and filial generations which reduce populations as a result of death,disturb development, malformations or malfunctions, extend development duration (Weissenberg et al., 1998: Friedman 2002: Nenaah 2011) or act as repellents (Chopa et al., 2009, Dinesh et al., 2014).

\section{REFERENCES}

Abdelrahman, M. A.; Azza, M. A. and Abeer, I. E. (2012). Efficacy of some plant volatile oils against the greater wax moth, Galleria mellonella L. ( Lepidoptera: Galleriadae). Egypt. J. Agric. Res., 90(2): 411-427.

Abdelsalam, A. M. (2009). Efficacy of some essential oils for wax moths control. $6^{\text {th }}$ international conference for Arabic beekeepers, Abha, KSA, 17-19 March .

Abou El-Ghar, G. E. S., Khalil, M. E. and Eid, T.M. (1996). Some biochemical effects of plant extracts in the black cutworm, Agrotis ipsilon (Hufn.) (Lep., Noctuidae).J.Appl.Ent.,482-477 (8)120 .
Aly, S. D. and Sahar, I. A. (2010). Efficacy of spearmint oil and powder as alternative of chemical control against C. maculatus in Cowpea Seeds. Egypt. Acad. J. Biol. Sci., 2(1): 53-61.

Aly, S. D. and Sahar, I. A. (2011). Oil and powder of spearmint as an alternative to sitophilus oryzae chemical control of wheat grains. J. Plant Prot. Res., 51)2): 146-150.

Assegid, G.; Erik, S. and Ingolf, L. (2004). Effect of the bee glue (propolis) on the calorimetrically measured metabolic rate and metamorphosis of the greater wax moth Galleria mellonella. Thermochimica Acta, 413(1-2): 63072.

Balandrin, M. F.; Klocke J. A.; Wurtele, E. S. and Bollinger, W. H. (1985). Natural plant chemicals: sources of industrial and medicinal materials. Sci., 228: $1154-1160$.

Browers , W. S. (1984 ). Insect- plant interaction : endocrine deviances . In organic and development of adaptation. Pitman Book London, pp.119-137.

Chandel, Y. S.; Sharma, S. and Verma, K. S. (2003) Comparative biology of the greater wax moth, Galleria mellonella L., and lesser wax moth, Achoria grisella. Forest Pest Management and Econ. Zool., 11(1): 69-74.

Charriere, J. D. and Imdorf, A. (1999). Protection of honey combs from moth damage. Am. Bee J., 139)8): 627-630.

Cheng, S. S.; Liu, J. Y.; Tsai, K. H.; Chen, W. J. and Chang, S. T. (2004). Chemical composition and mosquito larvicidal activity of essential oils from leaves of different Cinnamomumosmophloeum provenances. J. Agric. Food Chem., 52(14): 43954400.

Chokechaijaroenporn, O., Bunyapraphatsara, N. and Kongchensin, S. (1994) Mosquito repellent activities of Ocimum volatile oils. Phytomedicine $1,135-9$.,

Chopa, C.S.; Benzi, V.; Alzogaray, R.; Ferrero, A.A. (2009).Repellent activity of hexanic and ethanolic extracts from fruits of Solanum eleagnifolium (Solanaceae) against Blattella germanica (Insecta, Dictyoptera, Blattellidae) adults.Bol. Latinoam. Caribe. 8, 172-175.

Dew, M. J. and Evans, J. R. (1984). Peppermint oil for the irritable bowel syndrome; a multi center trialm. $\mathrm{Br}$. J. Clin. Pract., 38(11-12): 394-395.

Dinesh, D.S.; Kumari, S.; Kumar, V.; Das, P. (2014).The potentiality of botanicals and their products as an alternative to chemical insecticides to sandflies (Diptera: Psychodidae): A review. J. Vector Borne Dis. 51, 1-7.

El-Shall, S.S.A., Mohamed, H.F., (2005). The combined effect of gamma irradiation and plant extract (Barnoof) on the nutritional profile of the Black cutworm, Agrotis ipsilon (Hufn.) (Lepidoptera: Noctuidae), II - the effect on the F1 progeny during the 5th and 6th instars larvae. Arab J. Nucl. Sci. Appl. 38 (2),289.

El-Shazly, A. M. and Hussein, K. T. (2004). Chemical analysis and biological activities of the essential oil of Teucrium leucocladum Boiss. (Lamiaceae) . Biochem. Syst. and Ecol., 32(7): 665-674.

Emara, S., Bakr F. R., EL-Bermawy S., Abulyazid I. and Abdelwahab H. (2002). Biological effects of four botanical extracts on the different developmental stages of cotton leaf worm. Spodoptera littoralis. 2nd Inter. Conf.,Plant Protection Research Institute,Cairo.vol.1,904-916. 
Enan, E.; Beigler, M. and Kende, A. (1998). Insecticidal action of terpenes and phenols to cockroaches: effect on octopamine receptors. Paper presented at the International Symposium on

Erturk, O. (2006). Antifeedant and toxicity effects of some plant extracts on Thaumetopoae solitaria (Frey.) (Lep., Thaumetopoeidae). Turk. J. Biol. 30: 51-57

Fraser, H. W. (1997). The effect of different nonspecific male sex heromone component ratios on the behavior of the female greater wax moth, Galleria mellonella L. (Lepidoptera: Pyralidae). M.Sc.Thesis,Univ.Gueiph,Canada),

Friedman, M. (2002).Tomato glycoalkaloids: Role in the plant and in the diet. J. Agric. Food Chem. 50,5751-5780.

Garedew A.A., Schmolz E., and Lamprecht I., (2004) .Effect of the bee glue (propolis) on the calorimetrically measured metabolic rate and metamorphosis of the greater wax moth Galleria mellonella. Thermochimica Acta, vol. 413, 63-72,

Hany A. F. (2013). Effect of five essential oils as repellents against the Cowpea Beetle, Callosobruchus maculates (F.). Bull. Env. Pharmacol. Life Sci. 2(5): 23-27.

Huang, Y.; Ho, S. H.; Lee, H. C. and Yap, Y. L. (2002). Insecticidal properties of eugenol, isoeugenol and methyleugenol and their effects on nutritionof Sitophilus zeamais Motsch. (Coleoptera: Curculionidae) andTribolium castaneum (Herbst) (Coleoptera: Tenebrionidae). J. Stored Prod. Res., 38(5): 403-412.

Ildenize, B. S.; Cunha, A.; Alexandra, C. H.; Sawaya, F. M.; Mario, T.; Shimizua, M. C.; Marcucci, C.; Flavia, T.; Drezza, A.; Giovanna, S.;Poviaa, p. O. and Carvalhoa, A. (2004). Factors that influence the yield and composition of Brazilian propolis extracts. J. Braz. Chem. Soc., 15(6): 964-970.

Imdorf ,A., Bogdanov S., Ochoa R.I., and Calderone N.W., (1999).Use of essential oils for control of Varroa jacobsoni Oud. in honeybee colonies. Apidologie, vol. 30, 209-228.

Kartal, M.; Yildiz, S.; Kaya, S.; Kurucu, S. and Topcu, G. (2003). ntimicrobial activity of propolis samples from two different regions of Anatolia. J. Ethnopharmacol., 86(1): 69-73.

Keita, S. M.; Vincent, C.; Belanger, A. and Schmit, J. P. (2000). Effect of various essential oils on Callosobruchus maculatus (F.)[Coleoptera: Bruchidae]. J. Stored Prod. Res., 36(4): 355-364.

Keita, S. M.; Vincent, C.; Schmit, J. P.; Arnason, J. T. and Belanger, A. (2001). Efficacy of essential oil of Ocimum basilicum L. and $O$. gratissimum $\mathrm{L}$. applied as an insecticidal fumigant and powder to control Callosobruchus maculatus (Fab.) (Coleoptera: Bruchidae). J. Stored Prod. Res., 37(4): 339-349.

Khalaf, A. A.; Hussein, K. T. and Shoukry, K. K. (2009). Biocidal activity of two botanical volatile oils against the larvae of Synthesiomyia nudiseta (Wulp) (Diptera: Muscidae). Egypt. Acad. J. biolog. Sci., 2(1): 89-101.

Klocvke, J. A.; wagenea, B. V. and Bolandrin, M. F. (1986).The ellagitnnin geranin and its hydrolysis products isolated as issect groth inhibitors trom semiarid land plant.phytoche- mistry,25(1): 85-91.

Koul, O.; Walia, S. and Dhaliwal, G. S. (2008). Essential oils as green pesticides: potential and constraints. Biopesticides Int., 4(1): 63-84.
Kwon, M.; Ahn, Y. J.; Yoo, J. K. and Choi, B. R. (1996). Potent insecticidal activity of extracts from Ginkgo biloba leaves against Nilaparvata lugens (Homoptera: Delphacidae). Appl. Entomol. Zool., 31: 162-166.

Lee, K. G. and Shibamoto, T. (2001). Antioxidant property of aroma extract isolated from clove buds [Syzygium aromaticum (L.) Merr.Et Perry]. Food Chem., 74(4): 443-448.

Malarvannan, S. and Subashini, H. D. (2007). Effect of dodonaea angustifolia crude extract on biochemical profile of Helicoverpa armigera (Hubner) (Noctuidae: Lepidoptera). Biochem.and Cell. Arch., 7(1): 1-8.

Moawad, S. S. and Ebadah I. M. A. (2007). Impact of some natural plant oils on some biological aspects of potato tuber moth Phthorimaea operculella, (Zeller) (Lepidoptera: Gelechiidae) .Rese. J. Agric. and Biol. Sci., 3(2) 119-123.

Mohamed, H.F. (2013). Bioenergetics growth model for the effect of gamma irradiation and plant extract (Barnoof) on the progeny of Black cutworm, Agrotis ipsilon (Hufnagel) Applied Radiation and Isotopes 73, 101-108.

Mohamed, H.F., (2004). Inherited sterility induced by gamma irradiation and/or Barnoof plant extract on reproductive potential and mating ability of the black cutworm, Agrotis ipsilon (Hufngel) (Lepidoptera: Noctuidae). Isot. Radiat. Res. 36 (4), 713.

Mohamed, H.F., EL-Naggar, S.E.M., Mohamed, A.Z., (2004). The combined effect of gamma irradiation and plant extract barnoof on the nutritional profile to the black cutworm, Agrotis ipsilon, III. The effect on some haemolymph digestive enzyme activities. J. Egypt. Acad. Soc. Environ. Dev. (CMol. Biol.) 5 (2), 99.

Mohinder, S. J. (2001). Toxicity effect to garlic extracts on the eggs of Aedes aegypti (Diptera: Culicidae): A scanning electron microscopic study. J. Med. Entomol., 38(3): 446-450.

Mukhtar, M. D. and Tukur, A. (2000). Antibacterial activities of aqueous and ethanolic extract of Pistia stratioles. Niser J., 1(1): 51-59.

Mulungu, L. S.; Lupenza, G.; Rieuben, S. O. W. and Misangu, R. W.(2007). Evaluation of botanical products as Stored grain Protectant against maize weevil S. zeamaise. J. Entomol. Sci., 4: 258-262.

Nenaah, G.(2011) Toxic and antifeedant activities of potato glycoalkaloids against Trogoderma granarium (Coleoptera:Dermestidae). J. Stored. Prod. Res. 2011, 47, 185-190.

Netzurubanza, L. (1991) Quelques applications d'Ocimum canum: revue de la litte' rature, Rivista Italiana EPPOS, 10mes Journe'es Scientifiques de Digne les Bains, 703-6.

Ortiz, E. (1992). The encyclopedia of herbs, spices \&flavorings. London:Dorling Kindersley. pp: 36 37.

Owayss, A. A. and Abd-Elgayed, A. A. (2007). Potential efficacy of certain plant volatile oils and chemicals against greater wax moth, Galleria mellonella L.(lepidoptera: pyralidae). Bull. Ent. Soc. Egypt. Econ. Ser., (33): 67-75.

Owusu, E. O. (2000). Effect of some Ghanaian plant components on control of two stored- product insect pests of cereals. Journal of Stored Products Research, Vol. 37, 1, 85-91.

Pastagia, J. J. and Patel, M. B. (2007). Biology of Galleria mellonella L. on brood comb of Apis cerana F. J. of Plant Prot. and Envi.,4(2): 85-88. 
PDBC.(2007).Traning on Entomopathogenic nematode for insect pest control. Training manual for "Hands-on Training on Entomopathogenic nematode" 20th march to 29th March 2007, Project Directorate of Biological Control, Bangalore, India

Prowse, G. M.; Galloway, T. S. and Foggo, A. (2006). Insecticidal activity of garlic juice in two dipteran pests. Agric. Forest Entomol., 8(1): 1-6.

Regnault-Roger, C. and Hamraoui, A. (1995) Fumigant toxic activity and reproductive inhibition induced by Monoterpenes upon Acanthoscelides obtectus Say (Coleoptera), bruchid of kidney bean (Phaseolus vulgaris). Journal of Stored Product Research 31, 291-9.

Regnault-Roger, C., Hamraoui, A., Holeman, M., Theron, E. and Pinel, R. (1993) Insecticidal effect of essential oils from mediterranean aromatic plants upon Acanthoscelides obtectus Say, Coleoptera, bruchid of kidney bean (Phaseolus vulgaris L.). Journal of Chemical Ecology 19, 1233-44.

Rim, I. S. and Jee, C. H. (2006). Acaricidal effects of herbal essential oils against Dermatophagiodes farinae and D. pteronyssinus (Acari: Pyroglyphidae) and qualitative analysis of a herbal Mentha pulegium (Pennroyal). Korean J. Parasitol., 44(2): 133-138.

Salem, Nagwa, Y., Hoda, A. Ramadan and Elham, A. Sammour .(2003). Physiological and histopathological effects of some wild plant extracts on the cotton leaf worm Spodoptera littoralis (BOISD) (Lepidoptera Noctuidae). Bull. Ent. Soc. Egypt, Econ., 29 (113).

Sallam, H.A., Elnagar, S., Ibrahim, S.M., (1991). Effects of gamma radiation on reproductive potential of the black cut worm, Agrotis ipsilion (Hufn.). Arab J. Nucl. Sci. Appl. 24, 165-174.

Senanayake, U. M.; Lee, T. H. and Wills, R. B. H. (1978). Volatile constituents of cinnamon (Cinnamomum zeylanicum) oils. J. Agric. Food Chem., 26(4): 822-824.

Sharma, S. and Tyagi, B. R. (1991) .Character correlation, path coefficient and heritability analyses of essential oil and quality components in corn mint. J. of Gen. Virol., 45: 257-262.

Shasany, A. K.; Khanuja, S. P. S.; Dhawan, S. and Kumar, S. (2000). Positive correlation between mentholcontent and in and in vitro menthol tolerance in Mentha arvensis L. cultivars. J. Bio., 25(3): 263-266.

Shishir-Tandon, Mittal, A. K., Kasana, V. K. and Pant, A. K. (2004). Effect of essential oil of Elsholtzia densa L. on growth and reproduction of Spilosoma obliqua (Walker). Indian J. Ent., 66(3): 206-208.
Snedecor, G.W. and Cochran, W.G. (1967): Statistical methods. The Iowa state Univ. Press. Ames, Iowa, USA. 6th ed.

Sorkun, K.; Suer, B. and Salih, B. (2001). Determination of chemical composition of Turkish propolis. Z. Naturforsch., 56(7-8): 666-668.

Swamy, B. C. H.; Rajagopal, D. and Naik, M. I. (2006). Effect of plant products against larvae of greater wax moth. Mysore J. of Agric. Sci., 40(1): 125128.

Tripathi, A. K.; Prajapati, V.; Verma, N.; Bhal, J. R.; Bansal, R. P.; Khanuja, S. P. S. and Kumar, S. (2002). Bioactivities of the leaf essential oil of Curcuma longa (Var. Ch-66) on three species of stored-product beetles (Coleoptera). J. Econ. Entomol., 95(1): 183-189.

Tripathy, M. K., Singh, H. N. (2005). Synergistic effect of certain vegetable oils to the efficacy of synthetic pyrethroids for the control of Helicoverpa armigera (Hubner). Agric.Sci. Digest., 25(1): 1-5.

Velluti, A.; Sanchis, V.; Ramos, A. J.; Marı'n, S. (2003). Inhibitory effect ofcinnamon, clove, lemongrass, oregano and palmarose essential oil songrowth and fumonisin B1 production by Fusarium proliferatum inmaize grain. Int. J. Food Microbiol., 89: 145-154.

Weissenberg, M.; Levy, A.; Svoboda, J.A.; Ishaaya, I (1998).The effect of some solanum steroidal alkaloids andglycoalkaloids on larvae of the red flour beetle, Tribolium castaneum, and the tobacco hornworm, Manducasexta. Phytochemistry. 47, 203-209.

Wink, M. (1993) Production and application of phytochemicals from an agricultural perspective. In: "Phytochemistry and Agriculture" (T.A. van Beek, H. Breteler, eds.). Clarendon, Oxford, UK, Vol. 34. p. 171-213.

Yi, W., and Wetzstein. H.Y. (2010) Biochemical, biological, and histological evaluation of some culinary and medicinal herbs grown under greenhouse and field conditions.J. Sci. Food Agr. 90:1063-1070.

Zeng, L.; Lao, C. Z.; Cen, Y. J. and Liang, G. (2010). Study on the insecticidal activity compounds of the essential oil from Syzygium aromaticum against stored grain insect pests. $10^{\text {th }}$ InternationalWorking Conference on Stored Product Protection, pp. 766-771.

Zewdu A. and Gemechis L.(2016) Insecticidal action of honeybees propolis extract against larvae of lesser wax moth. Agric. Biol. J. N. Am., 2016, 7(6): 302306

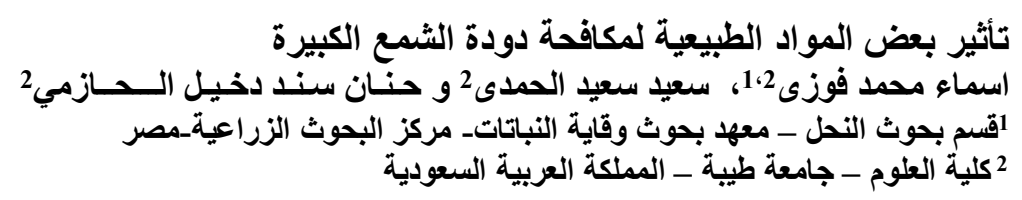

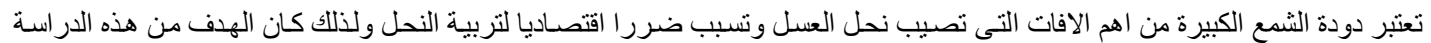

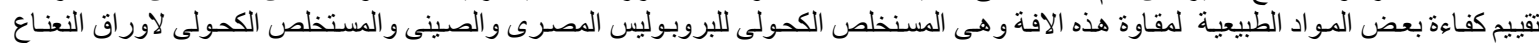

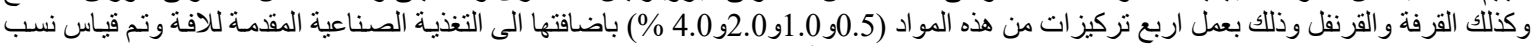

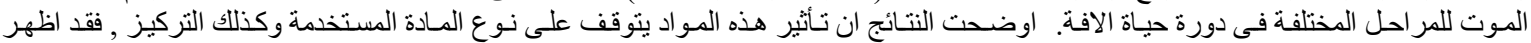

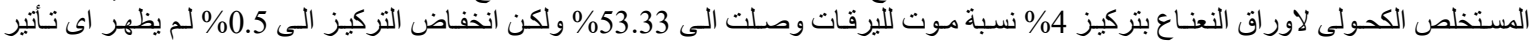

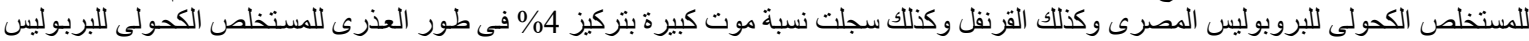

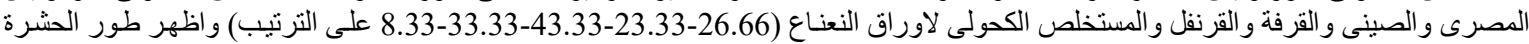

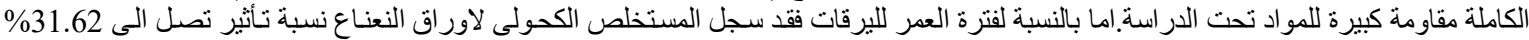

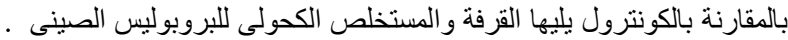

